\title{
Simultaneous blockade of AP-I and phosphatidylinositol 3-kinase pathway in non-small cell lung cancer cells
}

\author{
J Kikuchi' , I Kinoshita*,2, Y Shimizu², S Oizumi', M Nishimura', MJ Birrer ${ }^{3}$ and H Dosaka-Akita ${ }^{2}$ \\ 'First Department of Medicine, Hokkaido University School of Medicine, Sapporo, Japan; ${ }^{2}$ Department of Medical Oncology, Hokkaido University \\ Graduate School of Medicine, Sapporo, Japan; ${ }^{3}$ Cell and Cancer Biology Branch, National Cancer Institute, Bethesda, MD 20892, USA
}

c-Jun is a major constituent of AP-I transcription factor that transduces multiple mitogen growth signals, and it is frequently overexpressed in non-small cell lung cancers (NSCLCs). Earlier, we showed that blocking AP-I by the overexpression of a c-Jun dominant-negative mutant, TAM67, inhibited NSCLC cell growth. The phosphatidylinositol 3-kinase (PI3K)/Akt signal transduction pathway is important in transformation, proliferation, survival and metastasis of NSCLC cells. In this study, we used NCl-HI299 Tet-on clone cells that express TAM67 under the control of inducible promoter to determine the effects of inhibition of AP-I and PI3K on cell growth. The PI3K inhibitor, LY294002, produced a dose-dependent inhibition of growth in HI299 cells and that inhibition was enhanced by TAM67. TAM67 increased dephosphorylation of Akt induced by LY294002 and reduced the TPA response element DNA-binding of phosphorylated c-Jun. TAM67 increased GI cell cycle blockade induced by LY294002, which was partially associated with cyclin A decrease and p27 Kipl accumulation. Furthermore, TAM67 and LY294002 act, at least additively, to inhibit anchorage-independent growth of the HI299 cells. These results suggest that AP-I and PI3KJAkt pathways play an essential role in the growth of some NSCLC cells.

British Journal of Cancer (2008) 99, 2013-2019. doi:I0.1038/sj.bjc.6604782 www.bjcancer.com

Published online 18 November 2008

(c) 2008 Cancer Research UK

Keywords: AP-I; phosphatidylinositol 3-kinase pathway; non-small cell lung cancer; LY294002; TAM67

$c$-jun is the cellular homologue of the oncogene $v$-jun that was originally identified as the transforming sequence of avian sarcoma virus 17. c-Jun is also a central component of AP-1 that consists of homodimers and heterodimers of the Jun, Fos and ATF gene family members, and it regulates transcription through AP-1 and cAMP responsive elements (Angel et al, 1987, 1988; Curran and Franza, 1988; Sassone-Corsi et al, 1990). Although the role of c-Jun in human cancers remains to be defined, substantial evidence suggests that it is involved in cellular proliferation and transformation. Deregulated expression of c-Jun induces immortalised rat fibroblasts to grow in an anchorage-independent fashion (Schütte et al, 1989) depending on the induction of multiple c-Jun target genes (Kinoshita et al, 2003; Leaner et al, 2003, 2005; Hommura et al, 2004; Katabami et al, 2005). Recent studies reported that specific AP-1 blockade by a dominantnegative mutant of c-Jun, TAM67, inhibited the growth of some types of human cancer cells by causing G1 arrest (Ludes-Meyers et al, 2001; Liu et al, 2004; Suto et al, 2004).

Earlier studies (Wodrich and Volm, 1993; Szabo et al, 1996) suggested that c-Jun had a role in early events in the pathogenesis of lung cancers because it was highly expressed in $31-50 \%$ of patients with non-small cell lung cancers (NSCLCs), and it was also upregulated in atypical bronchial epithelium. In a previous study, we showed that TAM67 inhibited lung cancer growth both in vivo and in vitro using NCI-H1299 (H1299) NSCLC cells that expressed

\footnotetext{
*Correspondence: Dr I Kinoshita, Department of Medical Oncology, Hokkaido University Graduate School of Medicine, North 15, West 7 , Kita-ku, Sapporo 060-8638, Japan; E-mail: kinoshii@med.hokudai.ac.jp Revised 29 September 2008; accepted 23 October 2008; published online 18 November 2008
}

TAM67 under the control of an inducible promoter that blocked AP-1 activity (Shimizu et al, 2008). Taken together with its transforming properties, c-Jun may have pivotal roles in lung carcinogenesis and lung cancer growth.

The PI3K/Akt signal transduction pathway regulates various cellular processes including transformation, proliferation, survival and metastasis in a variety of cancer cells, including lung cancer cells (Kennedy et al, 1999; Brodt et al, 2000; Vivanco and Sawyers, 2002). Clear evidence shows that the PI3K/Akt signalling pathway is involved in lung carcinogenesis (Brognard et al, 2001; Chun et al, 2003; Lee et al, 2003; Tsao et al, 2003; Massion et al, 2004). Akt is frequently activated in both premalignant human bronchial epithelial cells and NSCLC cells. Akt activation may be an early event in lung tumorigenesis (West et al, 2003). Recent studies reported that the inhibition of PI3K activity by LY294002 reduced human cancer cell growth in vivo and in vitro by apoptosis or G1 cell cycle arrest (Casagrande et al, 1998; Hu et al, 2000; Semba et al, 2002; Gao et al, 2004; Takeda et al, 2004; Sourbier et al, 2006).

In this study, we investigated the antiproliferative effects of the inhibition of AP-1 and PI3K, alone and together, in the H1299 Tet-on clone cells using c-Jun dominant-negative mutants, TAM67 and LY294002.

\section{MATERIAL AND METHODS}

\section{Cell lines, culture conditions}

The human NSCLC cell lines, H1299, that expressed either TAM67 (H1299-TAM67) or green fluorescent protein (H1299-GFP) in a doxycycline-controlled manner were described previously 
A

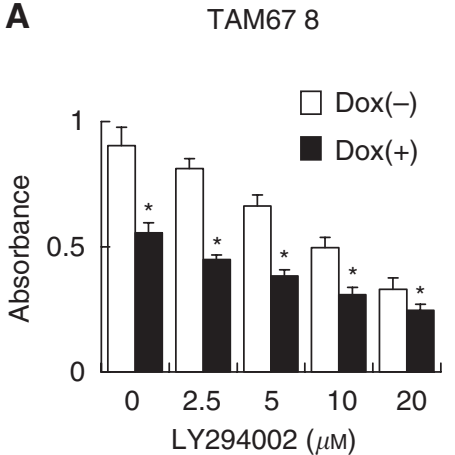

D

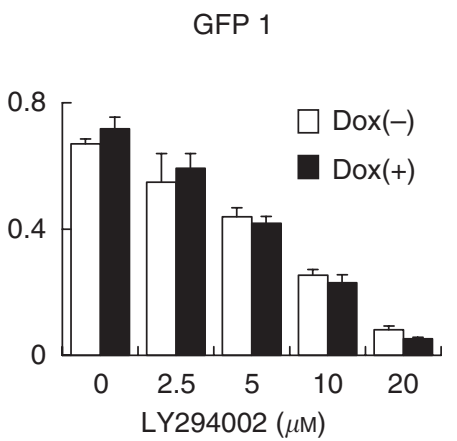

B

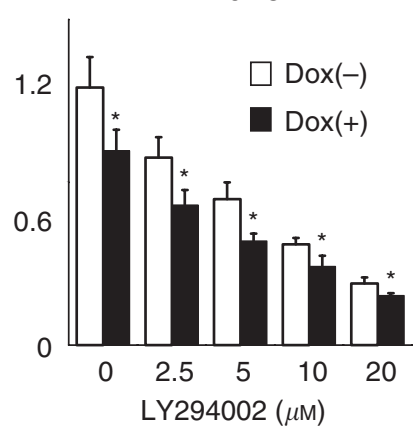

E

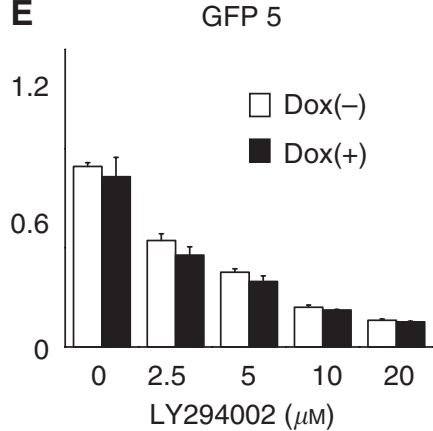

C

TAM67 38

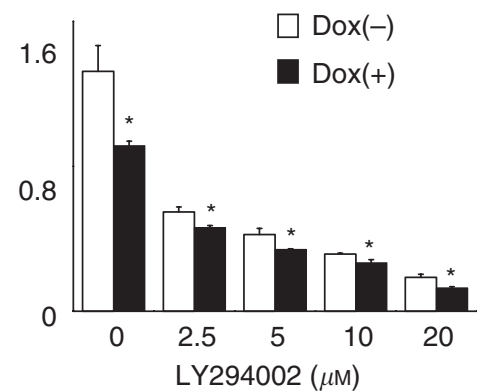

F $\quad$ GFP 8

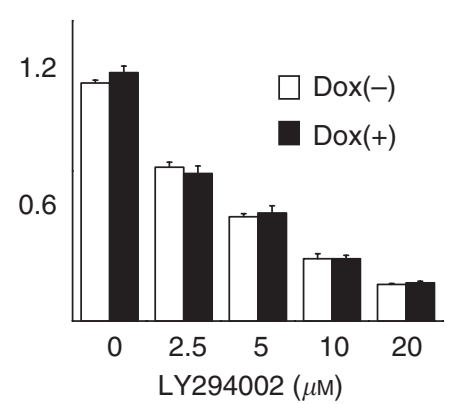

Figure I Effects on the cell growth of LY294002, TAM67 and their combination. (A-C) HI299-Tet-on-TAM67 clone cells (TAM67 nos. 8, 34 , and 38). (D-F) HI299-Tet-on-GFP clone cells (GFPs I, 5 and 8). The HI 299 clones were treated with solvent alone (0), or the indicated doses of LY294002 with or without TAM67 induction for $72 \mathrm{~h}$ at which time they were subjected to 3-(4,5-dimethylthiazol-2-yl)-2,5-diphenyltetrazolium bromide assays. Data points are the mean \pm s.d. of quadruplet samples in representative one of the three independent experiments. $* P<0.0$ l compared with cells treated with each concentration of LY294002 alone.

(Shimizu et al, 2008). Briefly, pLRT-TAM67 and -GFP were transfected into packaging Phoenix A cells by calcium phosphate transfection, and retroviruses were harvested after $48 \mathrm{~h}$ of transfection and infected into H1299 cells (Watsuji et al, 1997). Stable transfectants were selected using $5 \mu \mathrm{g} \mathrm{ml}^{-1}$ blasticidin (Invitrogen, Life Technologies Inc., Carlsbad, CA, USA) and screened by western blot analysis for inducibility of TAM67 expression in response to $2 \mu \mathrm{g} \mathrm{ml}^{-1}$ doxycycline. We chose clones TAM67 nos.8, 34 and 38 because of their highly inducible TAM67 expression in the presence of doxycycline. As controls, we used clones GFPs, 5 and 8 that had no inducible TAM67 expression.

Cells were cultured in RPMI 1640 (Invitrogen Life Technologies Inc.) medium supplemented with $10 \%$ foetal bovine serum (FBS) and $0.03 \%$ glutamine at $37^{\circ} \mathrm{C}$ in an atmosphere of $5 \%$ $\mathrm{CO}_{2}$. LY294002 (Sigma-Aldrich Co., St Louis, MO, USA) was dissolved in DMSO at $10 \mathrm{mM}$ and used at final concentration of $0.5-20 \mu \mathrm{M}$.

\section{Cell growth assays}

Cells were seeded at 2500-5000 cells per well in 96-well plates in normal growth medium with or without $2 \mu \mathrm{g} \mathrm{ml}^{-1}$ doxycyclin for $24 \mathrm{~h}$, followed by the addition of $0,2.5,5$ or $20 \mu \mathrm{M}$ of LY294002 for 3 days. Anchorage-dependent growth was measured in 96-well plates using an MTT (dimethyl thiozolyl-2',5'-diphenyl-2$H$-tetrazolium bromide)-based assay (non-radioactive proliferation assay, Promega Corp., Madison, WI, USA) as described previously (Sabichi et al, 1998).

Anchorage-independent growth assays were performed using $0.4 \%$ soft agarose (Seaplaque, FMC Corp., Rockland, ME, USA) in 6 -well plates with or without $0.1 \mu \mathrm{g} \mathrm{ml}^{-1}$ doxycyclin and LY294002 $(0.5,1$ or $2.5 \mu \mathrm{M})$ as described previously (Sabichi et al, 1998). After 2 weeks of incubation, colonies were stained with p-iodonitrote- trazolium violet (Sigma-Aldrich Co.) and counted using $\mathrm{NIH}$ Image ver 1.62 software (NIH, Bethesda, MD, USA).

\section{Western blotting}

Cell lysates from H1299 Tet-on clone cells grown in the absence or presence of doxycycline $\left(2 \mu \mathrm{g} \mathrm{ml}^{-1}\right)$ in combination with LY294002 were prepared by lysing the cells in radioimmune precipitation assay buffer ( $150 \mathrm{~mm} \mathrm{NaCl}, 1 \%$ Triton X-100, $1 \%$ deoxycholate, $0.1 \%$ SDS, $10 \mathrm{~mm}$ Tris (pH 7.4)) supplemented with $100 \mu \mathrm{g} \mathrm{ml}^{-1}$ leupeptin, $100 \mu \mathrm{g} \mathrm{ml}^{-1}$ aprotinin and $10 \mathrm{~mm}$ phenylmethylsulfonyl fluoride. The cell lysates were sonicated and centrifuged to remove debris, and protein concentrations were determined using the Bio-Rad Protein Assay kit (BioRad Laboratories, Hercules, CA, USA). Equal amounts of protein were separated on 12 or $15 \%$ SDS gels, transferred with nitrocellulose membranes (Amersham Biosciences Inc. St Albans, UK), and incubated with the following antibodies: anti-p27 $7^{\mathrm{kip} 1}$ (610242; BD Transduction Laboratories, KY, USA), anti-cyclin D1 (sc-246, Santa Cruz Biotechnology, Santa Cruz, CA, USA), anti-cyclin E (sc-247, Santa Cruz Biotechnology), anti-cyclin A (sc-751, Santa Cruz Biotechnology), anti-phosphorylated-Akt (Ser473; no. 9271, Cell Signaling Technology, Beverly, MA, USA), anti-Akt, (no. 9272, Cell Signaling Technology). Total cell extracts from Jurkat cells prepared with or without LY294002 were used as a positive or negative control of the assay for phosphorylated-Akt. The primary antibodies were detected using antirabbit or antimouse antibody conjugated with horseradish peroxidase (NA934V, NA931V, Amersham Biosciences Inc., St Albans, UK), and visualised using the Amersham ECL system after washing with TBST six times ( 5 min each) after the incubation of the first and second antibodies. The intensity of the bands after western blotting was determined by laser scanning of the films followed by quantitative densitometric analysis using NIH Image 
A $\quad$ TAM67 8
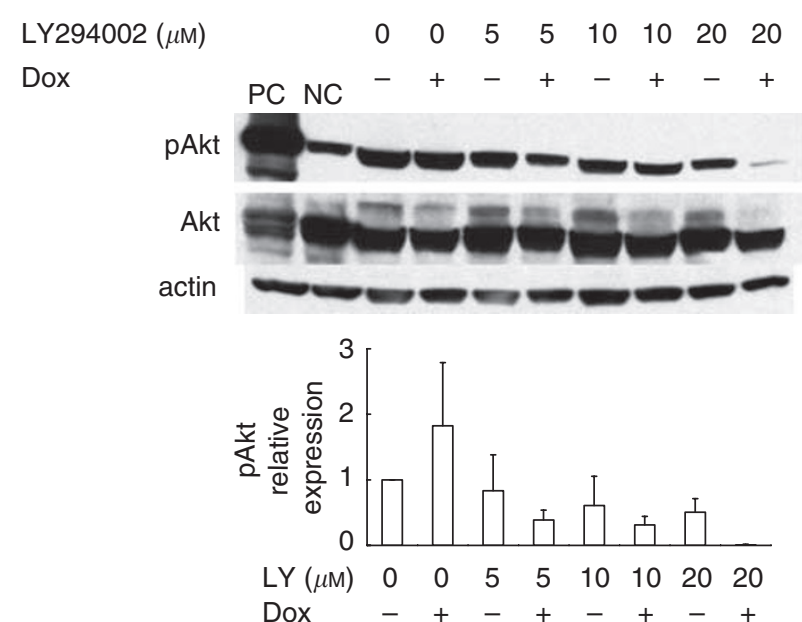

B GFP \#1
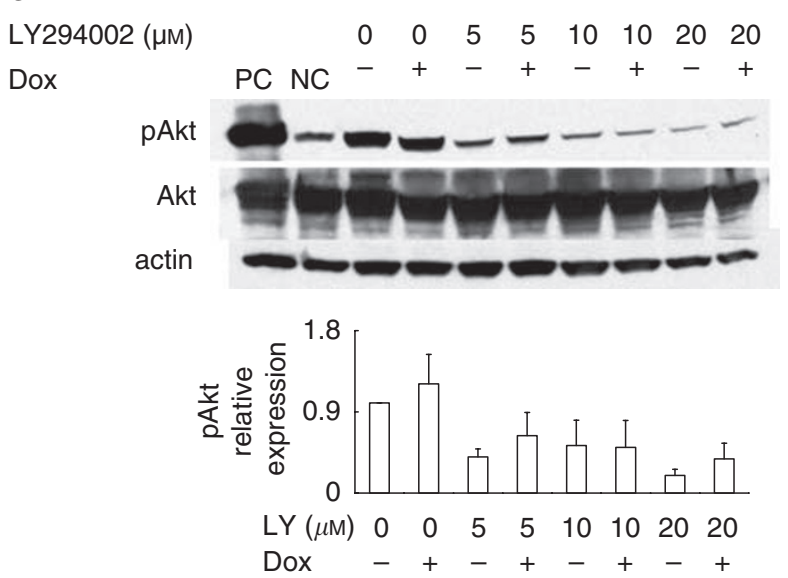

Figure 2 Effects on PI3K/Akt pathway activation of LY294002, TAM67 and their combination in HI299 cells. (A) HI299-Tet-on-TAM67 clone cells (TAM67 no. 8) and (B) HI299-Tet-on-GFP clone cells (GFP I). Western blots of cell lysates incubated with antibodies against phospho-Akt (S473) and Akt in cells treated with LY294002, the induction of TAM67 and their combination. Representative radiographs of three independent experiments. Standardisation was with actin measured in the same blots. Comparison of protein expression levels among the various conditions is based on the ratio of expression of a protein in each condition to that in non-treated one (set equal to I). NIH image 1.62 software was used to densitise and quantify the amount of the bands. The data show the average value of three independent experiments with error bars representing s.d. $\mathrm{PC}$, positive control; NC, negative control.

Ver 1.62 software. Standardisation was with actin measured in the same blots with antiactin antibody (A-2066, Sigma-Aldrich Co.).

\section{Cell cycle analysis}

H1299 Tet-on clone cells were cultured in 100-mm plates with or without $2 \mu \mathrm{g} \mathrm{ml}^{-1}$ doxycyclin for $24 \mathrm{~h}$, followed by the addition of 0,5 or $20 \mu \mathrm{M} \mathrm{LY} 294002$ for 3 days. Then, cells were trypsinized, washed twice with PBS and fixed in $70 \%$ ethanol at $-20^{\circ} \mathrm{C}$. Fixed cells were centrifuged and resuspended in $250 \mu \mathrm{g} \mathrm{ml}^{-1}$ RNase and $50 \mu \mathrm{g} \mathrm{ml}^{-1}$ propidium iodide (Sigma) for DNA staining. DNA content was measured by a FACScan flow cytometer (Becton Dickinson, San Jose, CA, USA) and two software packages: CellQuest 3.1 (BD Pharmingen, San Diego, CA, USA) and ModFit LT 2.0 (Verity Software House, Topsham, ME, USA).

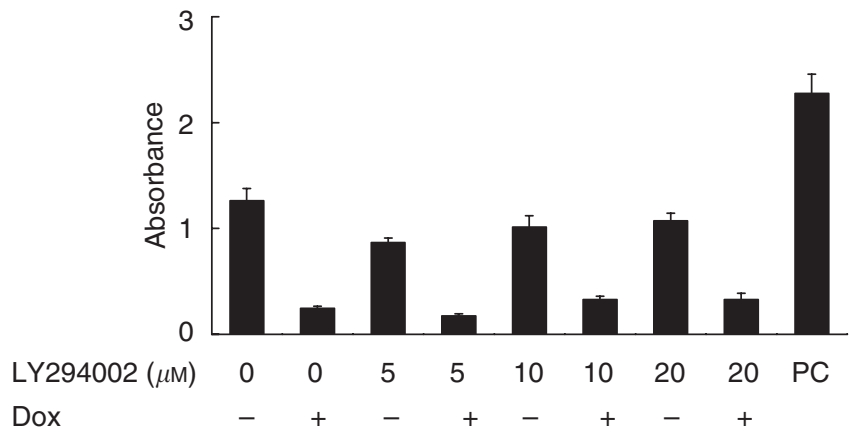

Figure 3 DNA-binding activity of p-c-Jun in TAM 8 analysed by the TransAM AP-I family transcription assay kit. TAM67 reduced the binding of phosphorylated c-Jun to TRE. Each value represents the mean \pm s.d. of triplicated samples in representative one of three independent experiments. PC, positive control.

\section{c-Jun activation assay}

Nuclear protein extracts were obtained from cell cultures using the nuclear extract kit (Active Motif, CA, USA) according to the manufacturer's instruction. The activation of c-Jun was measured using the TransAM ${ }^{\mathrm{TM}}$ AP-1 family transcription assay kit (Active Motif) according to the manufacturer's instruction (Debinski and Gibo, 2005; Polytarchou et al, 2005; Shimizu et al, 2008). This method measures the DNA-binding activity of AP-1 by ELISA. Briefly, $2.5 \mu \mathrm{g}$ of nuclear protein samples were incubated for $1 \mathrm{~h}$ in a 96-well plate coated with an oligonucleotide containing a TPA response element (TRE; $5^{\prime}$-TGAGTCA-3') that specifically binds with phosphorylated c-Jun (p-c-Jun) contained in nuclear extracts. For specificity control, an excess amount $(20 \mathrm{pmol})$ of mutant probe was added to the reaction in a competition assay. After washing, p-c-Jun antibody (1:500 dilutions) was added to these wells and incubated for $1 \mathrm{~h}$. Following incubation for $1 \mathrm{~h}$ with a secondary HRP-conjugated antibody (1:1000 dilution), specific binding was detected by colorimetric estimation at $450 \mathrm{~nm}$ with a reference wavelength of $655 \mathrm{nM}$. Note that the antibody against c-Jun recognises phosphorylated serine 73 of the transactivating domain of c-Jun and does not detect TAM67, in which most of the transactivating domain is deleted. Nuclear extracts from K562 cells stimulated by TPA were used as a positive control of the assay for c-Jun.

\section{Statistical analysis}

All values are presented as mean \pm s.d. Statistical significance was determined using Student's unpaired, two-tailed $t$-test.

\section{RESULTS}

\section{Induction of TAM67 enhanced antiproliferative effect of PI3K inhibitor LY294002}

Earlier, we showed that the induction of TAM67 inhibited anchorage-dependent growth in H1299 clones that express TAM67 (Shimizu et al, 2008). In this study, we investigated the growth inhibition of H1299 cells treated with LY294002 in combination with the induction of TAM67 (Figure 1A-F). LY294002 produced a dose-dependent inhibition of the growth of H1299 cells in the MTT assay. The induction of TAM67, but not GFP, enhanced the growth inhibition of LY294002 in the H1299 Tet-on clone cells. These results suggest that LY294002 and TAM67 have at least an additive effect on cell growth inhibition. 
A

(\%)

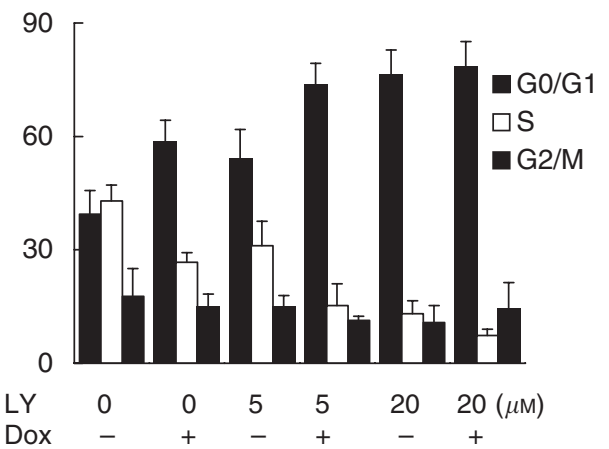

B

$(\%)$

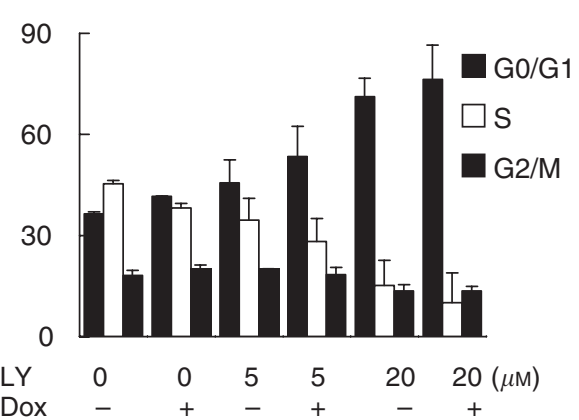

Figure 4 Effect on the proliferative arrest of LY294002, TAM67 and their combination. Cells were incubated with the indicated doses of LY294002 with or without induction of TAM67 for $72 \mathrm{~h}$. The percentage of cells in each phase was measured by an FACS flow cytometer and analysed using ModFitLT software. (A) Cell cycle analysis of TAM67 no. 8. The data show the average percentage of five independent experiments with error bars representing the s.d. (B) Cell cycle analysis of GFP I. The data show the average percentage of three independent experiments with error bars representing the s.d.

A

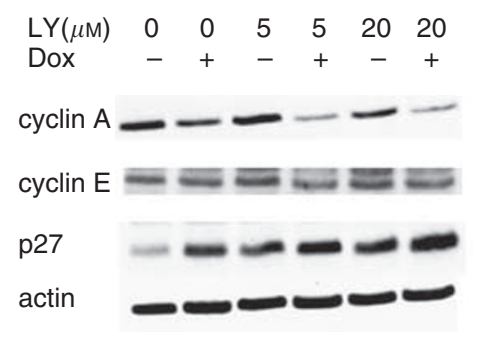

C

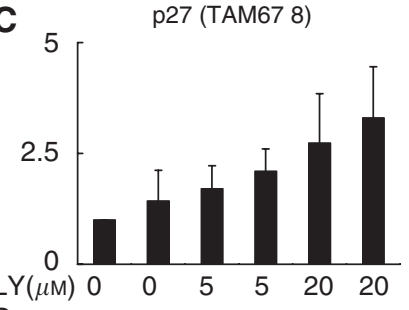

E

$$
\text { Cyclin A (TAM67 8) }
$$

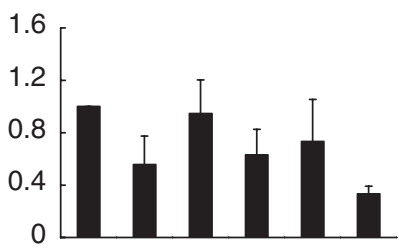

$\mathrm{LY}(\mu \mathrm{M}) 0 \quad 0 \quad 5 \quad 5 \quad 20 \quad 20$
B (GFP 1)
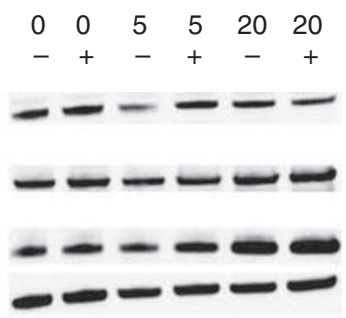

D

p27 (GFP 1)

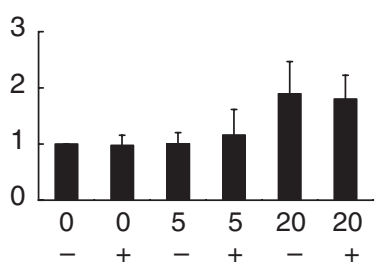

I

(GFP 5)

$\begin{array}{lllllll}\mathrm{LY}(\mu \mathrm{M}) & 0 & 0 & 5 & 5 & 20 & 20\end{array}$ Dox - + - + - +

$\operatorname{cyclin} \mathrm{A}=--$ p27

actin

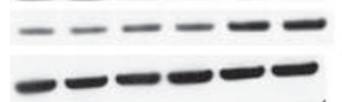

J (GFP 8)

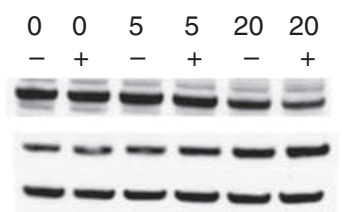

Figure 5 Representative western blots for cyclin A, cyclin E, p27 and actin. (A) TAM67 no. 8, (B) GFP I, (G) TAM67 nos.34 and (H) 38 , (I) GFP 5 and (J) GFP 8. (C-F) In TAM67 no.8 and GFP I, protein expression levels among the various conditions were compared on the basis of the ratio of expression of a protein in each condition to that in non-treated one (set equal to I). The data show the average value of six independent experiments with error bars representing the s.d. $\mathrm{NIH}$ image 1.62 software was used to densitise and quantify the amount of the bands.

The induction of TAM67 enhances dephosphorylation of Akt by LY294002

LY294002 inhibited the phosphorylation of Akt (Ser473) in a dosedependent manner (Figure 2). Interestingly, TAM67 further decreased the phosphorylation of Akt at 5-20 $\mu \mathrm{M}$ of LY294002, whereas TAM67 alone did not show such effects. This observation suggests that TAM67 and LY294002 may have a synergistic effect on inhibiting Akt activity.

\section{TAM67 inhibited AP-1 activity}

We determined the effects of single or combined treatment with LY294002 and TAM67 on AP-1 activity using ELISA-based 
A

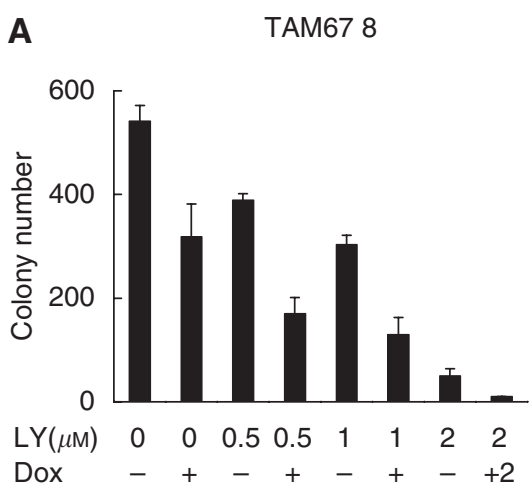

D

GFP 1

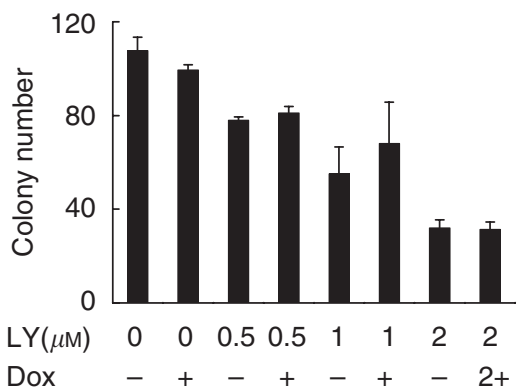

B 200 -

TAM67 34

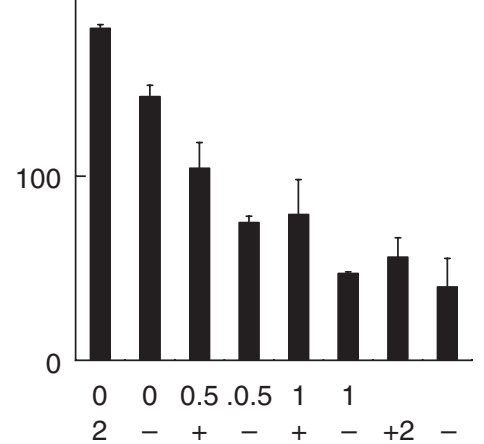

E 140

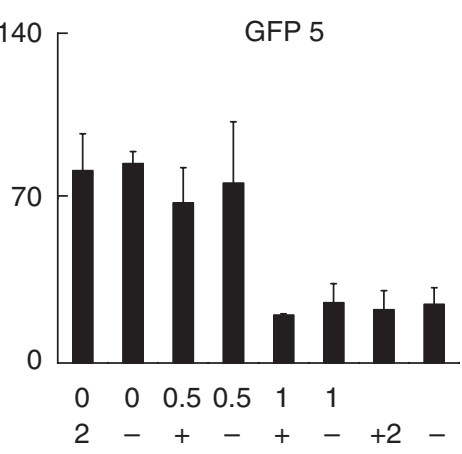

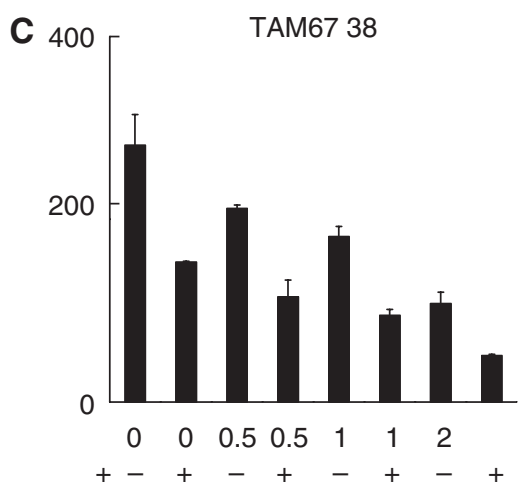

$\mathbf{F}$

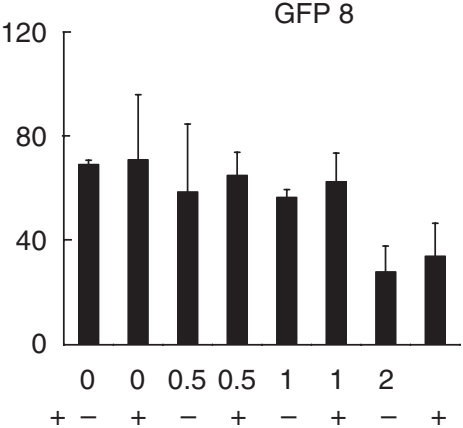

Figure 6 Inhibition of anchorage-independent growth by LY294002, TAM67 and their combination. Representative graphs of three independent experiments. (A-C) HI299-Tet-on-TAM67 clone cells (TAM67 nos. 8, 34 and 38). (D-F) HI299-Tet-on-GFP clone cells (GFPs I, 5 and 8). Data are means \pm s.d. of triplicate samples. Similar results were obtained in three independent experiments.

Trans $\mathrm{AM}^{\mathrm{TM}}$ AP-1 family transcription assay kit (Figure 3). TAM67 reduced the binding of $\mathrm{p}$-c-Jun to TRE at each concentration of LY294002, whereas LY294002 did not affect the binding. These results confirmed that TAM67 inhibited AP-1 activity over a wide range of concentrations of LY294002.

\section{The induction of TAM67 enhances G1 cell cycle block by LY294002}

We used flow cytometry to determine whether enhanced growth inhibition was because of cell cycle arrest or apoptosis of H1299 clones (Figure $4 \mathrm{~A}$ and $\mathrm{B}$ ). Earlier, we showed that the induction of TAM67, but not GFP, induced G1 cell cycle blockade in H1299 Teton clone cells (Shimizu et al, 2008). LY294002 increased the percentage of cells in G0/G1 phase with an associated decrease in $\mathrm{S}$ phase. The induction of TAM67, but not GFP, enhanced G1 cell cycle block by LY294002. Sub-G1 apoptotic fraction was not observed by LY294002, TAM67 or by both (data not shown). Lowdose $(5 \mu \mathrm{M})$ LY294002 with induction of TAM67 induced G1 cell cycle block similar to that induced by high-dose $(20 \mu \mathrm{M}) \mathrm{LY} 294002$. The additive effect between LY294002 and TAM67 was more apparent at a low dose $(5 \mu \mathrm{M})$ than a high dose $(20 \mu \mathrm{M})$ of LY294002. These results suggest that LY294002 and TAM67 produced an additive inhibition in cell growth by $\mathrm{G} 1$ cell cycle blockade in H1299.

\section{High-dose LY294002 upregulates p27 expression and TAM67 decreases cyclin A expression}

We measured the expression of p27, cyclins A, D1 and E that control the G1-S-phase transition to investigate how TAM67 enhanced G0/G1 arrest induced by LY294002 (Figure 5). Western blot analysis showed that high-dose LY294002 treatment increased p27 in both TAM67 no.8 and GFP 1 clones (Figure 5A-D). Expression of cyclin A decreased after the induction of TAM67 in
TAM67 no. 8 clone (Figure 5A and B). The increase of p27 by high-dose LY294002 and the decrease of cyclin A by TAM67 were also observed in other clones (Figure 5G-J). Although the induction of TAM67 slightly increased p27 in TAM67 no. 8 clones, this phenomenon was not observed in other TAM67 clones (Figure 5A-D and G-J). No significant changes were observed in cyclin E expression (Figure 5A and B), and cyclin D1 expression was not detected (data not shown). These results suggest that reduced expression of cyclin A by TAM67, and increased expression of p27 by high-dose LY294002 are involved in increased G1 arrest in H1299 cells.

\section{LY294002 and induction of TAM67 inhibit anchorage- independent growth}

We determined the effects of LY294002 and TAM67 on anchorageindependent growth (Figure 6A-F). LY294002 reduced anchorage-independent growth in a dose-dependent fashion. Induction of TAM67, but not GFP, enhanced the inhibition of anchorageindependent growth by LY294002. These results indicate that LY294002 and induction of TAM67 act, at least additively, to inhibit anchorage-independent growth of the H1299 cells.

\section{DISCUSSION}

This study showed the enhanced suppressive effects of a c-Jun dominant-negative mutant, TAM67 and LY294002 on both anchorage-dependent and -independent growth of a NSCLC cell line. These effects were associated with G1 cell cycle arrest, suggesting that some NSCLC cells depend on both AP-1 and PI3K/Akt pathways for cell growth.

The observed G1 cell cycle arrest was partially associated with decreased expression of cyclin A by TAM67 and increased expression of p27 by high-dose LY294002. The accumulation of 
p27 because of the inhibition of PI3K activity by LY294002, and its association with cell cycle arrest in the G1 phase have been shown in ovarian cancer, pancreatic ductal carcinoma and choroidal melanoma cell lines (Casagrande et al, 1998; Hu et al, 2000; Gao et al, 2004; Takeda et al, 2004). Cylin A functions during both G1-S and G2-M phases of the cell cycle (Girard et al, 1991; Pagano et al, 1992; Resnitzky et al, 1995). To our knowledge, the decreased expression of cyclin A by TAM67 was not reported previously, whereas TAM67 has been shown to inhibit breast cancer cell growth by reducing the expression of G1 cyclins D1 and E (LudesMeyers et al, 2001). These differences may be because of the different cell types. In immortalised rat fibroblasts, cyclin $\mathrm{A}$ is a direct c-Jun target gene and is necessary for c-Jun-induced anchorage-independent growth (Katabami et al, 2005). The increase of p27 by LY294002 and reduction of cyclin A expression by TAM67 may be involved in the enhanced antiproliferative effect of TAM67 and LY294002 when used in combination.

Using the H1299 NSCLC cells, Lee et al (2003, 2005) reported that PI3K/Akt and MKK4/JNK pathways cooperated to promote cell proliferation by maintaining cell survival in vivo and in vitro, and simultaneous blockade of both pathways induced apoptosis . In this study, using the same cells, blocking these pathways with LY294002 and TAM67 enhanced cell proliferative arrest more than either agent alone, but neither agent alone nor their combination induced apoptosis. Lee et al $(2003,2005)$ used JNK inhibitor, SP600215 or a dominant-negative mutant of MKK4 to inhibit MKK4/JNK pathways, whereas we used the dominant-negative mutant of c-jun, TAM67. They speculated that the MKK4/JNK inhibitor induced apoptosis because JNK directly phosphorylates $\mathrm{Bcl}-2$ in vitro and collaborates with Bcl-2 to mediate prolonged cell survival following various stress applications (Deng et al, 2001). TAM67 does not have direct effect on the phosphorylation of Bcl-2, although TAM67 inhibits AP-1 activity by quenching Jun, Fos and ATF family members to inhibit not only MKK4/JNK pathway but also MEK/ERK pathway. We speculate that these differences between JNK inhibitor and TAM67 may contribute to potent inhibition of the cell cycle, but no induction of apoptosis by the simultaneous blockade of the pathways with TAM67 and LY294002 in H1299 NSCLC cells.

We showed some synergistic effects of LY294002 and TAM67 on the phosphorylation of Akt (Ser473) that may be associated with growth inhibition. Leaner et al (2005) reported that c-Jun upregulates the expression of p75-Ras-GRF1, a guanine-nucleotide exchange factor (GEF) that results in an increase in GTP-Ras and PI3K activity . Therefore, we determined whether the induction of TAM67 affected the expression of p75-Ras-GRF1 protein. We did not observe significant change in the p75-Ras-GRF1 expression (data not shown). We speculate that other c-Jun/AP-1 target proteins are involved in decreased phosphorylation of Akt by TAM67 under the treatment of LY294002.

One of the hallmark properties of transformed cells and cancer cells is that they are capable of anchorage-independent growth in culture systems, and this property correlates very well with their in vivo oncogenic potential (Reed, 1999; Frisch and Screaton, 2001; Grossmann, 2002; Wang, 2004). Maeno et al (2006) reported that deregulated c-Jun expression was involved in the acquisition of anchorage independence in human lung carcinogenesis . Activated PI3K signalling plays a critical role in protecting cells from anoikis by inactivating certain key apoptotic molecules and simultaneously enhancing anchorage-independent cell cycle progression by inhibiting the cyclin inhibitors and enhancing certain CDK activity (Wang, 2004). The inhibition of anchorage-independent growth in H1299 cells by TAM67 and LY294002 that we observed is in line with these reports.

In conclusion, the results of this study suggest that AP-1 and PI3K/Akt pathways play an essential role for the growth of some NSCLC cells. Further investigations of the involved pathways in NSCLC cells and tissues are warranted to elucidate the molecular mechanisms of NSCLC growth and may ultimately help developing an effective therapeutic strategy for treating this cancer.

\section{REFERENCES}

Angel P, Allegretto EA, Okino ST, Hattori K, Boyle WJ, Hunter T, Karin M (1988) Oncogene jun encodes a sequence-specific trans-activator similar to AP-1. Nature 332: $166-171$

Angel P, Imagawa M, Chiu R, Stein B, Imbra RJ, Rahmsdorf HJ, Jonat C, Herrlich P, Karin M (1987) Phorbol ester-inducible genes contain a common cis element recognized by a TPA-modulated trans-acting factor. Cell 49: 729-739

Brodt P, Samani A, Navab R (2000) Inhibition of the type I insulin-like growth factor receptor expression and signaling: novel strategies for antimetastatic therapy. Biochem Pharmacol 60: 1101-1107

Brognard J, Clark AS, Ni Y, Dennis PA (2001) Akt/protein kinase B is constitutively active in non-small cell lung cancer cells and promotes cellular survival and resistance to chemotherapy and radiation. Cancer Res 61: 3986-3997

Casagrande F, Bacqueville D, Pillaire MJ, Malecaze F, Manenti S, BretonDouillon M, Darbon JM (1998) G1 phase arrest by the phosphatidylinositol 3-kinase inhibitor LY 294002 is correlated to up-regulation of p27Kip1 and inhibition of G1 CDKs in choroidal melanoma cells. FEBS Lett 422: $385-390$

Chun KH, Kosmeder JW, Sun S, Pezzuto JM, Lotan R, Hong WK, Lee HY (2003) Effects of deguelin on the phosphatidylinositol 3-kinase/Akt pathway and apoptosis in premalignant human bronchial epithelial cells. J Natl Cancer Inst 95: 291-302

Curran T, Franza BR (1988) Fos and Jun: the AP-1 connection. Cell 55: 395-397

Debinski W, Gibo DM (2005) Fos-related antigen 1 modulates malignant features of glioma cells. Mol Cancer Res 3: 237-249

Deng X, Xiao L, Lang W, Gao F, Ruvolo P, May WS (2001) Novel role for JNK as a stress-activated Bcl2 kinase. J Biol Chem 276: 23681-23688

Frisch SM, Screaton RA (2001) Anoikis mechanisms. Curr Opin Cell Biol 13: $555-562$
Gao N, Flynn DC, Zhang Z, Zhong XS, Walker V, Liu KJ, Shi X, Jiang BH (2004) G1 cell cycle progression and the expression of G1 cyclins are regulated by $\mathrm{PI} 3 \mathrm{~K} / \mathrm{AKT} / \mathrm{mTOR} / \mathrm{p} 70 \mathrm{~S} 6 \mathrm{~K} 1$ signaling in human ovarian cancer cells. Am J Physiol Cell Physiol 287: C281 - C291

Girard F, Strausfeld U, Fernandez A, Lamb NJ (1991) Cyclin A is required for the onset of DNA replication in mammalian fibroblasts. Cell 67: $1169-1179$

Grossmann J (2002) Molecular mechanisms of 'detachment-induced apoptosis - Anoikis'. Apoptosis 7: 247-260

Hommura F, Katabami M, Leaner VD, Donninger H, Sumter TF, Resar LM, Birrer MJ (2004) HMG-I/Y is a c-Jun/activator protein-1 target gene and is necessary for c-Jun-induced anchorage-independent growth in Ratla cells. Mol Cancer Res 2: 305-314

Hu L, Zaloudek C, Mills GB, Gray J, Jaffe RB (2000) In vivo and in vitro ovarian carcinoma growth inhibition by a phosphatidylinositol 3-kinase inhibitor (LY294002). Clin Cancer Res 6: 880-886

Katabami M, Donninger H, Hommura F, Leaner VD, Kinoshita I, Chick JF, Birrer MJ (2005) Cyclin A is a c-Jun target gene and is necessary for c-Jun-induced anchorage-independent growth in RAT1a cells. J Biol Chem 280: $16728-16738$

Kennedy SG, Kandel ES, Cross TK, Hay N (1999) Akt/Protein kinase B inhibits cell death by preventing the release of cytochrome $c$ from mitochondria. Mol Cell Biol 19: 5800-5810

Kinoshita I, Leaner V, Katabami M, Manzano RG, Dent P, Sabichi A, Birrer MJ (2003) Identification of cJun-responsive genes in Rat-1a cells using multiple techniques: increased expression of stathmin is necessary for cJun-mediated anchorage-independent growth. Oncogene 22: 2710-2722 Leaner VD, Donninger H, Ellis CA, Clark GJ, Birrer MJ (2005) p75-RasGRF1 is a c-Jun/AP-1 target protein: its up regulation results in increased Ras activity and is necessary for c-Jun-induced nonadherent growth of Rat1a cells. Mol Cell Biol 25: 3324-3337 
Leaner VD, Kinoshita I, Birrer MJ (2003) AP-1 complexes containing cJun and JunB cause cellular transformation of Ratla fibroblasts and share transcriptional targets. Oncogene 22: 5619-5629

Lee HY, Oh SH, Suh YA, Baek JH, Papadimitrakopoulou V, Huang S, Hong WK (2005) Response of non-small cell lung cancer cells to the inhibitors of phosphatidylinositol 3-kinase/Akt- and MAPK kinase 4/c-Jun NH2terminal kinase pathways: an effective therapeutic strategy for lung cancer. Clin Cancer Res 11: 6065-6074

Lee HY, Srinivas H, Xia D, Lu Y, Superty R, LaPushin R, Gomez-Manzano C, Gal AM, Walsh GL, Force T, Ueki K, Mills GB, Kurie JM (2003) Evidence that phosphatidylinositol 3-kinase- and mitogen-activated protein kinase kinase-4/c-Jun NH2-terminal kinase-dependent Pathways cooperate to maintain lung cancer cell survival. J Biol Chem 278: $23630-23638$

Liu Y, Lu C, Shen Q, Munoz-Medellin D, Kim H, Brown PH (2004) AP-1 blockade in breast cancer cells causes cell cycle arrest by suppressing G1 cyclin expression and reducing cyclin-dependent kinase activity. Oncogene 23: 8238-8246

Ludes-Meyers JH, Liu Y, Muñoz-Medellin D, Hilsenbeck SG, Brown PH (2001) AP-1 blockade inhibits the growth of normal and malignant breast cells. Oncogene 20: $2771-2780$

Maeno K, Masuda A, Yanagisawa K, Konishi H, Osada H, Saito T, Ueda R, Takahashi $\mathrm{T}$ (2006) Altered regulation of c-jun and its involvement in anchorage-independent growth of human lung cancers. Oncogene 25: $271-277$

Massion PP, Taflan PM, Shyr Y, Rahman SM, Yildiz P, Shakthour B, Edgerton ME, Ninan M, Andersen JJ, Gonzalez AL (2004) Early involvement of the phosphatidylinositol 3-kinase/Akt pathway in lung cancer progression. Am J Respir Crit Care Med 170: 1088-1094

Pagano M, Pepperkok R, Verde F, Ansorge W, Draetta G (1992) Cyclin A is required at two points in the human cell cycle. EMBO J 11: $961-971$

Polytarchou C, Hatziapostolou M, Papadimitriou E (2005) Hydrogen peroxide stimulates proliferation and migration of human prostate cancer cells through activation of activator protein-1 and up-regulation of the heparin affin regulatory peptide gene. J Biol Chem 280: $40428-40435$

Reed JC (1999) Mechanisms of apoptosis avoidance in cancer. Curr Opin Oncol 11: $68-75$

Resnitzky D, Hengst L, Reed SI (1995) Cyclin A-associated kinase activity is rate limiting for entrance into $S$ phase and is negatively regulated in G1 by p27Kip1. Mol Cell Biol 15: 4347-4352

Sabichi AL, Hendricks DT, Bober MA, Birrer MJ (1998) Retinoic acid receptor beta expression and growth inhibition of gynecologic cancer cells by the synthetic retinoid $\mathrm{N}$-(4-hydroxyphenyl) retinamide. J Natl Cancer Inst 90: 597-605
Sassone-Corsi P, Ransone LJ, Verma IM (1990) Cross-talk in signal transduction: TPA-inducible factor jun/AP-1 activates cAMP-responsive enhancer elements. Oncogene 5: 427-431

Schütte J, Minna JD, Birrer MJ (1989) Deregulated expression of human c-jun transforms primary rat embryo cells in cooperation with an activated c-Ha-ras gene and transforms rat-1a cells as a single gene. Proc Natl Acad Sci USA 86: $2257-2261$

Semba S, Itoh N, Ito M, Harada M, Yamakawa M (2002) The in vitro and in vivo effects of 2-(4-morpholinyl)-8-phenyl-chromone (LY294002), a specific inhibitor of phosphatidylinositol $3^{\prime}$-kinase, in human colon cancer cells. Clin Cancer Res 8: $1957-1963$

Shimizu Y, Kinoshita I, Kikuchi J, Yamazaki K, Nishimura M, Birrer MJ, Dosaka-Akita H (2008) Growth inhibition of non-small cell lung cancer cells by AP-1 blockade using a cJun dominant-negative mutant. Br J Cancer 98: 915-922

Sourbier C, Lindner V, Lang H, Agouni A, Schordan E, Danilin S, Rothhut S, Jacqmin D, Helwig JJ, Massfelder T (2006) The phosphoinositide 3-kinase/Akt pathway: a new target in human renal cell carcinoma therapy. Cancer Res 66: 5130-5142

Suto R, Tominaga K, Mizuguchi H, Sasaki E, Higuchi K, Kim S, Iwao H, Arakawa T (2004) Dominant-negative mutant of c-Jun gene transfer: a novel therapeutic strategy for colorectal cancer. Gene Ther 11: 187-193

Szabo E, Riffe ME, Steinberg SM, Birrer MJ, Linnoila RI (1996) Altered cJUN expression: an early event in human lung carcinogenesis. Cancer Res 56: $305-315$

Takeda A, Osaki M, Adachi K, Honjo S, Ito H (2004) Role of the phosphatidylinositol $3^{\prime}$-kinase-Akt signal pathway in the proliferation of human pancreatic ductal carcinoma cell lines. Pancreas 28: 353 - 358

Tsao AS, McDonnell T, Lam S, Putnam JB, Bekele N, Hong WK, Kurie JM (2003) Increased phospho-AKT (Ser(473)) expression in bronchial dysplasia: implications for lung cancer prevention studies. Cancer Epidemiol Biomarkers Prev 12: 660-664

Vivanco I, Sawyers CL (2002) The phosphatidylinositol 3-Kinase AKT pathway in human cancer. Nat Rev Cancer 2: 489-501

Wang LH (2004) Molecular signaling regulating anchorage-independent growth of cancer cells. Mt Sinai J Med 71: $361-367$

Watsuji T, Okamoto Y, Emi N, Katsuoka Y, Hagiwara M (1997) Controlled gene expression with a reverse tetracycline-regulated retroviral vector (RTRV) system. Biochem Biophys Res Commun 234: 769-773

West KA, Brognard J, Clark AS, Linnoila IR, Yang X, Swain SM, Harris C, Belinsky S, Dennis PA (2003) Rapid Akt activation by nicotine and a tobacco carcinogen modulates the phenotype of normal human airway epithelial cells. J Clin Invest 111: $81-90$

Wodrich W, Volm M (1993) Overexpression of oncoproteins in non-small cell lung carcinomas of smokers. Carcinogenesis 14: 1121-1124 